\title{
Causes Of Delinquency Among Children Living In Juvenile Jail (Karachi) \& Its Effects On Their Personalities
}

\author{
Shagufta Nasreen \\ \& \\ Aliyah Ali \\ Women's Studies \\ University of Karachi
}

\begin{abstract}
Behaviour of children and adolescents is a growing concern all over the world. Children are future of any country but unfortunately they are the most neglected group in Pakistan. According to statistics, young people (15-24 years) living in Pakistan numbered 36 million in 2004. One of the major problems is children's involvement in crimes and this issue is becoming very grave. There are different reasons for children's commitment of crimes. These include poverty, joblessness, as well as thrill and action. In jail, they face difficult time and most of them come out with the stigma of "criminal" which continues to haunt them in their life and affect their personality, family and society at large. The need is to implement the existing laws and identify the reasons of increase in crime and take actions to decrease the rate of crime in this age group.
\end{abstract}

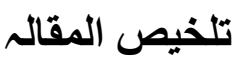

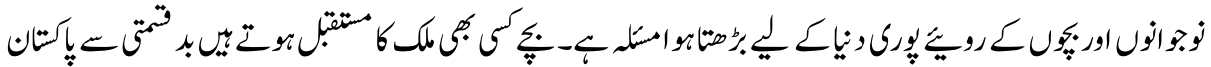

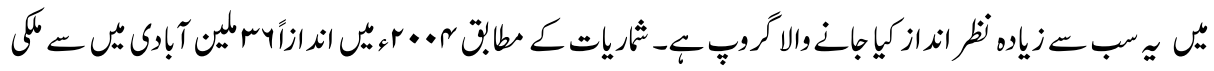

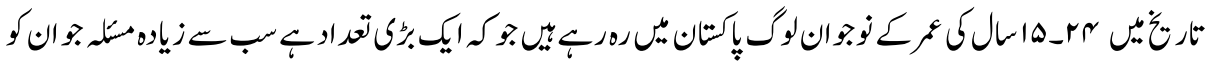

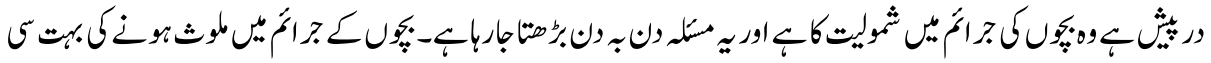

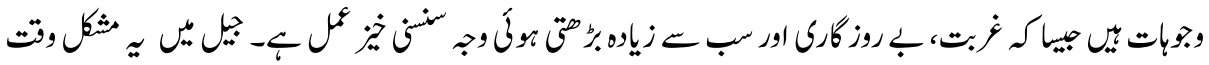

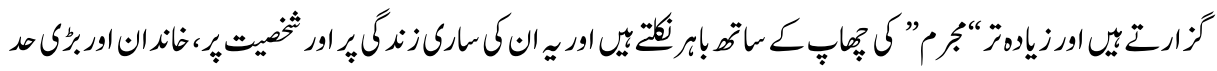

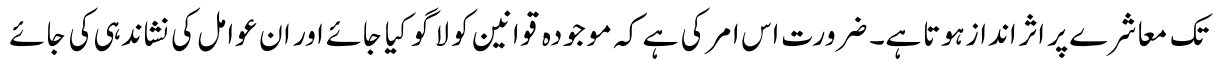

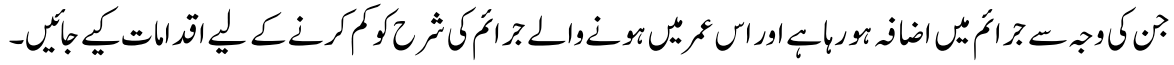


The worst sin towards our fellow creatures is not to hate them, but to be indifferent to them; that is the essence of inhumanity 'The Devil's Disciple' George Bernard Shaw

Every society has different culture, norms, traditions and behaviors. In this global age, there are problems which are interconnected and these spread in different countries become of similar or different reasons. With advanced technologies and fastest means of communications, the problem of children committing crimes could not be solved even in the developed countries. Children are not only committing ordinary crimes, but they are also getting involved in dangerous criminal activities including robbery and terrorism. According to ${ }^{1}$ World Book of Encyclopedia, "Childhood extends from birth until some time pass the age of 20 ". Labeling a child as criminal affects the whole life of a child. The term 'Delinquent' is used instead of 'Criminal' but behavior of society plays a very important role in making such a person a good citizen.

Now a days we see and hear a lot of about children committing crimes. It is a serious problem of our society and quite complicated. We cannot shy away from this problem.

\section{Background}

Juvenile delinquency refers to criminal acts performed by juveniles. Most legal systems prescribe specific procedures for dealing with juveniles, such as juvenile detention centers. There are a multitude of different theories on the causes of crime, most if not all of which can be applied to the causes of youth crime. Youth crime is an aspect of crime which receives great attention from the news media and politicians. ${ }^{2}$

Children were viewed as non-persons until the 1700 's. They did not receive special treatment or recognition. Discipline then is what we now call abuse. There were some major assumptions about life before the 1700's. The first assumption is that life was hard, and you had to be hard to survive. The people of that time in history did not have the conveniences that we take for granted. For example, the medical practices of that day were primitive in comparison to present-day medicine. Marriages were more for convenience, rather than for child-bearing or romance. The second assumption was that infant and child mortality were high. It did not make sense to the parents in those days to create an emotional bond with children. There was a strong chance that the children would not survive until adulthood.

At the end of the 18th century, "The Enlightenment" appeared as a new cultural transition. This period of history is sometimes known as the beginning of reason and humanism. People began to see children as flowers, which needed nurturing in order to bloom. It was the invention of childhood, love and nurturing instead of beatings to stay in line. Children had finally begun to emerge as a distinct group. It started with the upper- 
class, who was allowed to attend colleges and universities. ${ }^{3}$ Throughout all time there has been delinquency. It may not have had the delinquency label, but it still existed. In ancient Britain, children at the age of seven were tried, convicted, and punished as adults. There was no special treatment for them, a hanging was a hanging. Juvenile crime is mentioned as far back as ancient Sumeria and Hammurabi, where laws concerning juvenile offenders first appear in written form. ${ }^{4}$

How children's involvement in crimes is the problem of every country i.e. "The number of delinquency cases handled in U.S. juvenile courts remained virtually unchanged from 2000 through 2005. An estimated 1.7 million delinquency cases were handled in juvenile courts nationwide in 2005. During the two decades since 1985, however, the juvenile court caseload has been anything but static. From 1985 through 1997, the number of delinquency cases handled climbed steadily (61\%) and from 1997 through 2005, the delinquency caseload dropped $9 \%$. Juvenile courts handled $46 \%$ more cases in 2005 than in $1985 .^{5}$

Locked up for long periods of time, many children are subjected to appalling conditions of confinement that violate international standards. Often held with adults and subjected to violence at the hands of guards and other detainees, children in confinement are frequently denied adequate food, medical and mental health care, education, and access to basic sanitary facilities. ${ }^{6}$

Pakistan has seen many critical changes in this period most of which have been marked by conflict. The country is seeing many problems due to economic recession, structural adjustment programs from the Bretton Woods Institutions, downsizing in many public and private institutions resulting in decrease in quality of life with almost monthly increase in price of essential items. These have had an immense impact on almost all spheres of life. Family life obviously suffered due to this changes and percentage of delinquency is increased. According to the society for Protection and Rights of the Child (SPARC) provided disturbing figures regarding the incarceration of juveniles. SPARC's figure indicate that $90 \%$ of incarcerated juveniles were under trial, the highest figure in Sindh, where only 16 were convicted out of the 391 incarcerated. The incarceration of juveniles continued at an alarming rate. In Karachi alone, around 30 criminal cases were registered against juveniles every month. ${ }^{7}$ This situation shows clear picture of increasing social and psychological destruction of our children. Pakistan is also a signatory of the Convention on the Rights of Children, but has failed to perpetuate sufficient laws for the protection of juveniles in police custody or in jails.

To explore these aspects a research was conducted in the Juvenile jail of Karachi in 2003. The jail was previously functioning in the building of present district jail, Malir and it was named "Juvenile Jail Karachi". The present building is an extension of central prison facility of Karachi. It was constructed to ease overcrowding in that jail. On completion, 
the government established "Juvenile Jail" in this building and notified the Malir Jail building as "District Jail" for hosting adult inmates involved in minor offences. Accordingly Juvenile Jail inmates were transferred here in November, 1993. The name "Juvenile Jail Karachi" was changed in 1998 into "Youthful Offenders Industrial School Karachi”.

The objective of this research is to discuss the causes of children's involvement in crimes, its effect on their personal lives, situation of Jail where children are living, the legal rights of children and awareness about these rights.

The jail building spreads over an area of 5 acres. The age limit of children living in this jail is between 14 to 18 years. In recent years the increasing number of violent crimes committed by children is very alarming. It alerts us regarding the danger coming towards our society. This highlights the problem of increase in crimes which has assumed an alarming rate.

There are different theories explaining children's involvement in crime. According to social control theories, humans engage in deviant or irregular behavior because breaking rules is fascinating and exciting. It is normal that the children want to meet their needs in the easiest way possible and this is more so when social control is weak or missing which may be due to:

a) Failure to form internal controls during childhood,

b) Breakdown of already established internal control, especially adolescence,

c) Social disorganization particularly in the family that ends due to weak external control"

According to another theory, the social learning approach, criminal behavior results when the individual has learned the motives, drives, rationalizations and attitudes favorable to the violation of law, in excess of definitions unfavorable to the violation of law.

This approach offers another explanation. The negative treatment from others (strain) tends to generate negative emotions such as anger, frustration and resentment, which in turn creates pressure for corrective action, with delinquency being one possible response. According to a WHO report, poverty, joblessness and the lack of real employment opportunities may promote violence by generating a sense of frustration, low self esteem, hopelessness about the future and family instability. Other reasons are family problems, problems in schools, bad company, lack of recreational activities, use of drugs, abuse and delinquency, mass media, lack of faith and belief, socio-economic factors and crime, thrill and curiosity. 
For the collection of data for present study, an interviewing schedule was designed. Originally the data were to be collected through distribution of the questionnaire but due to the low rate of literacy of the respondents, the interview schedule was designed. The present study has been conducted from non-structural population. The number of children living in juvenile jail was 350 at the time of research (June-July 2003). Where as my population are 60 because of the limitation of time.

Result of the study shows a serious problem about these children. When we punish a child because of his/her mistake, then the main purpose is that the child, must realize that he/she did something wrong and he/she should never repeat it again. But when children go to jail because of any crime very few think that they will never repeat the same mistake. However it all depends on the treatment they receive in jail, the procedure of court and most importantly the behavior of people after their release. Crimes affect children's lives in every aspect. They start thinking about their future at an early stage of their life. In this age, the children usually are hopeful and full of energy, but when you meet a child living in the juvenile jail, you see a disappointed, hopeless and full of fear child. They think that they don't have a future. For example, a child in juvenile jail was charged for murder, robbery and keeping weapons. When asked questions about his future, he replied confidently and without any fear that "Death is the future I see". Crimes make children look and think above their age. They commit crimes without knowing the future results. There are different news about horrible incidents occurring especially in the West where school students murdered their school teachers and students involved in Columbian massacre. The reason identified by the teams of investigators and psychologists was social climate, bullying, music, video games.

It suggests that illiteracy can not be declared as the major cause of crime. The research shows that majority of children were literate. (see table 1) They were involved in different types of crimes. The majority was involved in murder and robbery. They gave different reasons for these crimes include unemployment and poverty. But the alarming thing is that anger and thrill has been identified as one of the major problems and we can relate that with one of the incidents I have mentioned about crime. One of the children, 14 years of age, son of a doctor, mentioned that a boy used to harass his sister. He initially politely advised him to respect women and their dignity. But the boy continued his activities. Then he used a metal object, wore on punch, to beat him but a scar on neck caused death of the harasser. He mentioned that what he did was a right thing that a brother should do, and if he had left this place, then continue he could have his studies etc. Some of the children committing these types of crimes were not fearful of this situation. They were involved in crimes with partners. It shows that many crimes were conducted by sheer pressure. Friends are the important part of our life. Sometimes children commit crimes because their friends force them to do so. Especially criminals, in many ways, stimulate children to commit crimes. Sometimes they use children in illegal activity. The bad company of friends may be a step towards crimes. The partners were 
their friends and in some cases relatives. Some of cause said that they are here for false allegations. Most of them had a lawyer which shows that they were aware of the procedure. More than half of children were abused during police custody and it was physical abuse which included beating. None of them said they were abused sexually, but there are different researches mentioning about sexual abuse of these children.

\section{Conclusion}

Children are the future of our nation. Being a developing country, our children have suffered from many problems. These children on streets begging, using drugs and stealing things without knowing their future needs attention of the society. The need is to think about the solution of this problem. The causes of crimes in Pakistani society are poverty, joblessness and lack of real employment opportunities, thrill and many others. The need is to address these problems and make policy and plans and programmes to empower our youth and help making them good citizens.

\section{End Notes}

${ }^{1}$ Editor: William H. Nault, World Book of Encyclopedia (pg. No. 403, Vol.3, 2002)

${ }^{2}$ Juvenile delinquency - Retrieved on August 20, 2009 www. wikipedia, the free encyclopedia.htm

${ }^{3}$ Juvenile Delinquency :A Brief History, Retrieved on August 20, 2009 www.wiu.edu/users/mucdr5/jdhist.htm

${ }^{4}$ http://ojjdp.ncjrs.org/ojstatb/html/qa251.html.20jan2005 Retrieved on 12th August, 2009

${ }^{5}$ http://en.wikipedia.org/wiki/Columbine High School massacre

${ }^{6} \mathrm{http}: / /$ www.hrw.org/en/news-all/690, Retrieved on 12th August, 2009

${ }^{7}$ Women and Juveniles in Jail, State of Human Rights in 2007, Human Rights Commission of Pakistan. Pg.79

\section{References}

Anees Jilani, (1999). Juvenile justice in Pakistan, Islamabad: SPARC

Khan Ilyas, Laws Relating to Children, Pakistan Law House, Karachi, 1997.

Aulakh Chaudhry Abdulmajeed, Crime Punishment and Treatment in Islamic Republic of Pakistan, Lahore, 1986. 
Thomas Black, Understanding Social Science Research, Sage Publications, London, 2002.

Tehzeeb ul Hassan Gilgiti, Causes of Juvenile Delinquency, Monthly Al-Qanoun, Islamabad, July, 2002.

Anees Jilani, Criminals are made not born, SAHIL, Lahore, January-March 2003.

Ordinance for Juvenile Justice Federal Government of Pakistan, Published by SPARC, Islamabad, 2000.

\section{Webliography}

Juvenile delinquency www. wikipedia, the free encyclopedia.htm

Juvenile Delinquency: A Brief History www.wiu.edu/users/mucdr5/jdhist.htm

http://ojjdp.ncjrs.org/ojstatb/html/qa251.html.20jan2005

http://en.wikipedia.org/wiki/Columbine_High_School_massacre

http://www.hrw.org/en/news-all/690

\section{Appendix}

Table 1: Distribution of respondents by education

\begin{tabular}{|l|c|l|}
\hline Education & F & $\%$ \\
\hline Literate & 32 & $53.00 \%$ \\
\hline Illiterate & 28 & $47.00 \%$ \\
\hline Total & 60 & $100 \%$ \\
\hline
\end{tabular}

Table 2: Distribution of respondents by type of crime.

\begin{tabular}{|l|c|c|}
\hline Type of Crime & F & $\%$ \\
\hline Murder & 12 & $20.00 \%$ \\
\hline Robbery & 12 & $20.00 \%$ \\
\hline Stealing & 07 & $12.00 \%$ \\
\hline Pick Pocketing & 00 & 00 \\
\hline Use Of Drugs & 05 & $08.00 \%$ \\
\hline Other & 24 & $40.00 \%$ \\
\hline Total & 60 & $100 \%$ \\
\hline
\end{tabular}


Table 3: Distribution of respondents by cause of crime

\begin{tabular}{|l|c|c|}
\hline Cause of Crime & F & $\%$ \\
\hline Unemployment & 05 & $08.00 \%$ \\
\hline Poverty & 05 & $08.00 \%$ \\
\hline Anger & 07 & $12.00 \%$ \\
\hline Thrill & 11 & $18.00 \%$ \\
\hline any other & 32 & $54.00 \%$ \\
\hline Total & 60 & $100 \%$ \\
\hline
\end{tabular}

Table 4: Distribution of respondents by feeling before committing crime

\begin{tabular}{|l|c|c|}
\hline Feelings & F & $\%$ \\
\hline Scared & 04 & $07.00 \%$ \\
\hline Calm & 29 & $48.00 \%$ \\
\hline Un comfortable & 04 & $07.00 \%$ \\
\hline Others & 23 & $38.00 \%$ \\
\hline Total & 60 & $100 \%$ \\
\hline
\end{tabular}

Table 5: Distribution of respondents by partner in crime.

\begin{tabular}{|l|c|c|}
\hline Partner in Crime & F & $\%$ \\
\hline Yes & 38 & $63.00 \%$ \\
\hline No & 13 & $22.00 \%$ \\
\hline False allegation & 09 & $15.00 \%$ \\
\hline Total & 60 & $100 \%$ \\
\hline
\end{tabular}

Table 5.1: Distribution of respondents by relation with his partner

\begin{tabular}{|l|c|c|}
\hline Relation with Partner & F & $\%$ \\
\hline Relatives & 07 & $18.00 \%$ \\
\hline Friends & 25 & $66.00 \%$ \\
\hline Others & 06 & $16.00 \%$ \\
\hline Total & 38 & $100 \%$ \\
\hline
\end{tabular}

Table 6: Distribution of respondents by having any lawyer

\begin{tabular}{|l|c|c|}
\hline Having any Lawyer & F & $\%$ \\
\hline Yes & 36 & $60.00 \%$ \\
\hline No & 24 & $40.00 \%$ \\
\hline Total & 60 & $100 \%$ \\
\hline
\end{tabular}

Table 7: Distribution of respondents according to abuse in police custody

\begin{tabular}{|l|c|c|}
\hline Abuse in Custody & $\mathrm{F}$ & $\%$ \\
\hline Yes & 41 & $68.00 \%$ \\
\hline No & 19 & $32.00 \%$ \\
\hline Total & 60 & $100 \%$ \\
\hline
\end{tabular}


Table 7.1: Distribution of respondents according to type of abuse

\begin{tabular}{|l|c|c|}
\hline Type of Abuse & $\mathrm{F}$ & $\%$ \\
\hline Physical & 34 & $83.00 \%$ \\
\hline Mental & 07 & $17.00 \%$ \\
\hline Total & 41 & $100 \%$ \\
\hline
\end{tabular}

Shagufta Nasreen is Lecturer at the Centre of Excellence for Women's Studies, University of Karachi, Pakistan. She is enrolled in M.Phil/ Ph.D. Her areas of interest are: Gender and Development, Media and Environment.

Aliyah Ali is Lecturer at the Centre of Excellence for Women's Studies, University of Karachi, Pakistan. She is enrolled in M.Phil/ Ph.D. Her areas of interest are: Women and Health, Gender and Development, Women Work, and Technology. 